\title{
Saltwater intrusion into tidal freshwater marshes alters the biogeochemical processing of organic carbon
}

\author{
S. C. Neubauer ${ }^{1, *}$, R. B. Franklin ${ }^{2}$, and D. J. Berrier ${ }^{2}$ \\ ${ }^{1}$ Baruch Marine Field Laboratory, University of South Carolina, Georgetown, South Carolina, USA \\ ${ }^{2}$ Department of Biology, Virginia Commonwealth University, Richmond, Virginia, USA \\ * now at: Department of Biology, Virginia Commonwealth University, Richmond, Virginia, USA
}

Correspondence to: S. C. Neubauer (sneubauer@vcu.edu)

Received: 2 June 2013 - Published in Biogeosciences Discuss.: 1 July 2013

Revised: 2 October 2013 - Accepted: 8 November 2013 - Published: 11 December 2013

\begin{abstract}
Environmental perturbations in wetlands affect the integrated plant-microbial-soil system, causing biogeochemical responses that can manifest at local to global scales. The objective of this study was to determine how saltwater intrusion affects carbon mineralization and greenhouse gas production in coastal wetlands. Working with tidal freshwater marsh soils that had experienced $\sim 3.5 \mathrm{yr}$ of in situ saltwater additions, we quantified changes in soil properties, measured extracellular enzyme activity associated with organic matter breakdown, and determined potential rates of anaerobic carbon dioxide $\left(\mathrm{CO}_{2}\right)$ and methane $\left(\mathrm{CH}_{4}\right)$ production. Soils from the field plots treated with brackish water had lower carbon content and higher $\mathrm{C}: \mathrm{N}$ ratios than soils from freshwater plots, indicating that saltwater intrusion reduced carbon availability and increased organic matter recalcitrance. This was reflected in reduced activities of enzymes associated with the hydrolysis of cellulose and the oxidation of lignin, leading to reduced rates of soil $\mathrm{CO}_{2}$ and $\mathrm{CH}_{4}$ production. The effects of long-term saltwater additions contrasted with the effects of short-term exposure to brackish water during three-day laboratory incubations, which increased rates of $\mathrm{CO}_{2}$ production but lowered rates of $\mathrm{CH}_{4}$ production. Collectively, our data suggest that the long-term effect of saltwater intrusion on soil $\mathrm{CO}_{2}$ production is indirect, mediated through the effects of elevated salinity on the quantity and quality of autochthonous organic matter inputs to the soil. In contrast, salinity, organic matter content, and enzyme activities directly influence $\mathrm{CH}_{4}$ production. Our analyses demonstrate that saltwater intrusion into tidal freshwater marshes affects the entire process of carbon mineralization, from the availability of organic carbon through its terminal
\end{abstract}

metabolism to $\mathrm{CO}_{2}$ and/or $\mathrm{CH}_{4}$, and illustrate that long-term shifts in biogeochemical functioning are not necessarily consistent with short-term disturbance-type responses.

\section{Introduction}

Biogeochemical processes occurring in wetland soils can be important to the local, regional, and global cycles of elements including carbon, nitrogen, phosphorus, and sulfur. These processes can be influenced by changes in environmental conditions such as temperature, soil moisture, oxygen $\left(\mathrm{O}_{2}\right)$ availability, nutrient supply, and salinity (e.g., Updegraff et al., 1998; Sundareshwar et al., 2003; Baldwin et al., 2006; Bridgham et al., 2008). Environmental changes can have direct effects on biogeochemical transformations (e.g., the presence of $\mathrm{O}_{2}$ inhibits methanogenesis; Segers, 1998) or the effects can be indirect and driven by interactions among ecosystem components (e.g., nutrient additions increase plant productivity and subsequent $\mathrm{O}_{2}$ transport to subsurface soil, thereby enhancing methane $\left(\mathrm{CH}_{4}\right)$ oxidation; Keller et al., 2006). Prolonged shifts in environmental conditions can lead to important feedbacks within and between the biotic and abiotic components of the ecosystem, causing long-term changes in biogeochemical functioning that are not necessarily consistent with short-term disturbance-type responses (after Keller et al., 2006; Laiho, 2006; Bridgham et al., 2008).

High rates of plant productivity and low rates of decomposition have led to the accumulation of an estimated 45-70\% of all terrestrial organic carbon (C) in wetland soils (Mitra 
et al., 2005). Rates of $\mathrm{C}$ accumulation are generally a small fraction of total $\mathrm{C}$ inputs to a wetland (e.g., Lindroth et al., 2007; Megonigal and Neubauer, 2009), indicating that the vast majority of $\mathrm{C}$ inputs are mineralized or otherwise removed (e.g., by hydrological export or herbivory). The mineralization of soil organic matter first requires the breakdown of complex polymers into subunits small enough for microbial uptake. This depolymerization is mediated by extracellular enzymes, which generate soluble sugars that can serve as electron donors to heterotrophic microbes. The terminal steps of $\mathrm{C}$ mineralization under anaerobic conditions result in the production of carbon dioxide $\left(\mathrm{CO}_{2}\right)$ and/or $\mathrm{CH}_{4}$, with natural wetlands accounting for $\sim 20-30 \%$ of global $\mathrm{CH}_{4}$ emissions (Schlesinger, 1997; Conrad, 2009; Bridgham et al., 2013).

Tidal freshwater marshes and swamps occur at the landward end of estuaries, where the influence of astronomical tides is felt but river discharge is sufficient to maintain freshwater conditions (Barendregt and Swarth, 2013). With storm surges, droughts, and accelerating rates of sea level rise, there is increasing oceanic influence in the tidal freshwater zone that manifests as transient to sustained increases in salinity (hereafter, "saltwater intrusion"). The objective of the current study was to determine how saltwater intrusion affects $\mathrm{C}$ mineralization in tidal freshwater marsh soils. We examined potential rates of $\mathrm{CO}_{2}$ and $\mathrm{CH}_{4}$ production under anaerobic conditions using soils that were exposed to low-salinity water for several days in the laboratory and soils that had experienced experimental in situ saltwater intrusion for $\sim 3.5 \mathrm{yr}$. Additionally, we measured the activity of extracellular enzymes involved in the breakdown of cellulose, hemicellulose, and lignin, since the enzymatic depolymerization of these substrates is often the rate-limiting step for decomposition (Sinsabaugh, 1994). These data were combined with information on soil properties to generate a conceptual model of how saltwater intrusion influences $\mathrm{C}$ biogeochemistry in tidal freshwater marsh soils.

\section{Materials and methods}

\subsection{Study site and field sampling}

Brookgreen Gardens contains 1084 ha of tidal freshwater marshes and swamps that are located on the Waccamaw River, South Carolina, or its tidal tributaries. We worked in a 0.9 ha tidal freshwater marsh within Brookgreen Gardens that was vegetated by a herbaceous community consisting of Zizaniopsis miliacea (giant cutgrass), Peltandra virginica (arrow arum), Phyla lanceolata (lanceleaf fogfruit), Cicuta maculata (water hemlock), and $\sim 30$ other species (Neubauer and Sutter, 2013). The site is at the upper end of the tidal prism and is flooded with up to $10-30 \mathrm{~cm}$ of water on many, but not all, of the semi-diurnal high tides. From June 2008 through November 2011 ( $3.5 \mathrm{yr}$ ), we manipulated 15 plots $\left(0.37 \mathrm{~m}^{2}\right.$ each $)$ in this marsh by increasing freshwater inputs (+fresh plots, $n=5$ ) or by raising porewater salinities with brackish water additions (+salt plots, $n=5$ ). A set of control plots $(n=5)$ was not manipulated. Throughout the field manipulations, porewater salinity in the control and + fresh plots was typical of the tidal freshwater zone (salinity $<0.2$ ), but salinities in the + salt plots were representative of oligohaline environments (salinity $\sim 2-5$; see Neubauer (2013a) for details on the field manipulations and porewater salinity monitoring). Plant species richness was reduced by roughly 50-75\% (from 8-14 down to 3-6 species plot ${ }^{-1}$ ), leaving $Z$. miliace and $P$. lanceolata as the most common species in the +salt plots (Neubauer and Sutter, 2013). Coincident with this decrease in species richness was a decrease in aboveground plant biomass and a 26-44\% decrease in gross ecosystem productivity (Neubauer, 2013b).

In November 2011, beginning the day after the field manipulations ceased, soil cores $\left(55 \mathrm{~cm}^{2},>28 \mathrm{~cm}\right.$ depth) were collected from all fifteen plots over a three-day period. One core from each plot was sectioned in the field $(0-3 \mathrm{~cm}$ and every $5 \mathrm{~cm}$ thereafter to the base of the core) and used for all measurements described herein. We focused our analyses on the surface soils $(0-3 \mathrm{~cm})$ and on two depths in the root zone (8-13 and 23-28 cm), although some biogeochemical measurements were also made on soils from the $3-8 \mathrm{~cm}$ interval. Samples were kept cool in the field and stored at $4{ }^{\circ} \mathrm{C}$ upon return to the laboratory.

\section{2 $\mathrm{CO}_{2}$ and $\mathrm{CH}_{4}$ production potentials}

\subsubsection{Responses to long-term saltwater intrusion}

For all soil samples, we measured the potential rates of anaerobic $\mathrm{CO}_{2}$ and $\mathrm{CH}_{4}$ production over two-day periods (after Neubauer et al., 2005). Measurements on the 0-3, 8-13, and 23-28 cm soil sections were made in Dec 2011, roughly one month after field sample collection. For logistical reasons, a randomly selected subset of plots $(n=8)$ was processed and analyzed one week; samples from the remaining seven plots were analyzed the following week. Prior to use, soils were homogenized under anaerobic conditions (i.e., in a $\mathrm{N}_{2}$ filled glove bag), with large roots and woody debris removed, but no effort was made to remove fine roots. Working in the glove bag, $\sim 7 \mathrm{~g}$ soil (wet weight) were weighed into $125 \mathrm{~mL}$ serum bottles ( $n=2$ bottles per plot per depth). Soil slurries were prepared by adding $7 \mathrm{~mL}$ of deoxygenated water to the soil aliquots. Water from the tidal freshwater portion of the Waccamaw River ( salinity $=0.0$, conductivity $=124$ $127 \mu \mathrm{S} \mathrm{cm}^{-1}, \mathrm{pH}=7.05-7.16$ ) was used directly to make soil slurries for samples from the control and + fresh plots. For samples from the + salt plots, low-salinity water (salinity $=2.0$, conductivity $=3.5-3.6 \mathrm{mS} \mathrm{cm}^{-1}, \mathrm{pH}=7.18-7.20$ ) was prepared by mixing Waccamaw River water with water from the flow-through seawater system at the Baruch Marine Field Laboratory. Freshwater and brackish water blanks 
(7 $\mathrm{mL}$ per bottle) were also prepared each week to quantify $\mathrm{CO}_{2}$ and $\mathrm{CH}_{4}$ production occurring in the source waters. The serum bottles were sealed while inside the glove bag, and the headspace was flushed with ultra-high purity $\mathrm{N}_{2}$ for $15 \mathrm{~min}$. After an overnight pre-incubation period, the headspace of all bottles was again flushed with $\mathrm{N}_{2}$ for at least 5 min prior to incubating the samples in the dark at $25^{\circ} \mathrm{C}$. Gas samples were collected at $0,4,24,28$, and $48 \mathrm{~h}$ by vortexing the slurry for $15 \mathrm{sec}$, injecting a $5 \mathrm{~mL}$ aliquot of $\mathrm{N}_{2}$, and then withdrawing an equal volume of headspace gas for subsequent analyses.

\subsubsection{Responses to short-term saltwater intrusion}

In January 2012, we conducted a second $\mathrm{CO}_{2}$ and $\mathrm{CH}_{4}$ production experiment to determine the short-term effects of elevated salinity on potential rates of anaerobic $\mathrm{CO}_{2}$ and $\mathrm{CH}_{4}$ production. This assay used soil from the $3-8 \mathrm{~cm}$ interval. Ideally, we would have used soil from the $0-3 \mathrm{~cm}$ interval, where rates were highest and the difference between + fresh and + salt soils was greatest (see Results, below), but there was insufficient soil remaining after conducting the first set of biogeochemical rate measurements. Samples were prepared anaerobically, as described above, with the difference that slurries were made with Waccamaw River water that was unmanipulated (salinity $=0.0$, conductivity $=140 \mu \mathrm{S} \mathrm{cm}^{-1}, \mathrm{pH}=7.13$ ) or adjusted using seawater to a salinity of 2.0 (conductivity $=3.7 \mathrm{mS} \mathrm{cm}^{-1}, \mathrm{pH}=7.24$ ) or 5.0 (conductivity $=8.9 \mathrm{mS} \mathrm{cm}^{-1}, \mathrm{pH}=7.32$ ). Hereafter, these will be referred to as "freshwater," "low salinity," and "moderate salinity" slurries, respectively. There were two replicates per salinity level per plot. After an overnight preincubation period, the headspace of the serum bottles was flushed with ultra-high purity $\mathrm{N}_{2}$ and sampling began. The experiment ran for $48 \mathrm{~h}$, with gas samples collected at five time points during that period.

\subsubsection{Analytical methods}

The $\mathrm{CO}_{2}$ and $\mathrm{CH}_{4}$ concentrations were measured within hours of sample collection using a LI-COR LI-7000 infrared gas analyzer (for $\mathrm{CO}_{2}$; LI-COR Biosciences, Lincoln, NE, USA) and a Shimadzu GC-14A gas chromatograph with flame ionization detector (for $\mathrm{CH}_{4}$; Shimadzu Scientific Instruments, Columbia, MD, USA). The detection limit was at least 25 ppmv for $\mathrm{CO}_{2}$ and $0.5 \mathrm{ppmv}$ for $\mathrm{CH}_{4}$, with a precision of $\pm 0.4 \%$ for each gas (median coefficient of variation for 132 pairs of duplicate sample injections). Potential rates of $\mathrm{CO}_{2}$ and $\mathrm{CH}_{4}$ production were calculated using linear regression analysis and normalized to soil dry weight, organic matter, and $\mathrm{C}$ content. Fluxes were typically linear over time, with median correlation coefficients of 0.99 for $\mathrm{CO}_{2}$ and 0.97 for $\mathrm{CH}_{4}$. Four percent of all reported fluxes had correlation coefficients between 0.65 and 0.85 , which was attributed to a combination of very low rates of gas production and instrument variability (i.e., noise).

\subsection{Extracellular enzyme assay}

Extracellular enzyme activity was measured for soil from the $0-3,8-13$, and $23-28 \mathrm{~cm}$ depth increments of each field plot within one month of sampling. The ability of soil microbes to access the labile $\mathrm{C}$ pool (cellulose) was assessed by quantifying the activities of $\beta$-1,4-glucosidase (hereafter, "glucosidase", E.C. 3.2.1.21) and 1,4- $\beta$-cellobiosidase ("cellobiosidase", E.C. 3.2.1.91). We also measured the activities of $\beta$-D-xylosidase ("xylosidase", E.C. 3.2.1.37) and phenol oxidase (E.C. 1.10.3.2), which are associated with the breakdown of more recalcitrant fractions of the soil $\mathrm{C}$ pool (hemicellulose and lignin, respectively). Activity of each enzyme was determined using artificial substrates obtained from Sigma-Aldrich Co. Ltd. (St. Louis, MO, USA). Soil slurries were prepared for each sample by adding $1.0 \mathrm{~g}$ fresh soil to $100 \mathrm{~mL}$ deionized (DI) water and then sonicating at $15 \mathrm{~W}$ for 2 min using the Misonix Sonicator 3000 (Newtown, CT, USA).

Following modified protocols from Marx et al. (2001), the activities of glucosidase, cellobiosidase, and xylosidase were measured fluorometrically using methylumbelliferone (MUB)-linked substrates: 4-MUB $\beta$-D-glucopyranoside (Sigma \#M3633), 4-MUB $\beta$-D-cellobioside (Sigma \#M6018) and 4-MUB- $\beta$-D-xylopyranoside (Sigma \#7008), respectively. Three analytical replicates (containing $50 \mu \mathrm{L}$ soil slurry, $50 \mu \mathrm{L}$ of $0.1 \mathrm{M}$ MES buffer at $\mathrm{pH} 6.1,100 \mu \mathrm{L}$ of $1.2 \mathrm{mM}$ MUB-linked substrate), a negative control (50 $\mu \mathrm{L}$ sterile DI water, $50 \mu \mathrm{L}$ buffer, $100 \mu \mathrm{L}$ substrate), and eight quenched standards $(50 \mu \mathrm{L}$ soil slurry, $150 \mu \mathrm{L}$ buffer with 0-1400 pmol of MUB) were prepared in black 96-well microplates for each soil sample. Substrate was always added last. Prepared microplates were placed on a shaker table and incubated in the dark at $30^{\circ} \mathrm{C}$ for $1 \mathrm{~h}$ (for cellobiosidase) or $4 \mathrm{~h}$ (for glucosidase and xylosidase) before being read on a BioTek Synergy 2 microplate reader (Winooski, VT, USA) for approximately $6 \mathrm{~h}$ at $30^{\circ} \mathrm{C}$ (excitation $360 \mathrm{~nm}$ and emission $460 \mathrm{~nm}$ ). Activity levels were calculated using the quench curve for each sample and plotted vs. incubation time. The slope of this linear regression (all $R^{2}>0.95$ ) was used to calculate activity rates.

Colorimetric assays of phenol oxidase activity followed Stursova et al. (2006) and were conducted in clear 96-well microplates using the substrate l-DOPA $(6.5 \mathrm{mM}$ final concentration). For each soil, we ran triplicate sample assays (containing $50 \mu \mathrm{L}$ soil slurry, $50 \mu \mathrm{L}$ of $50 \mathrm{mM}$ sodium bicarbonate buffer at $\mathrm{pH} 6.1,100 \mu \mathrm{L}$ 1-DOPA) and negative substrate controls $(50 \mu \mathrm{L}$ soil slurry, $100 \mu \mathrm{L}$ buffer, $50 \mu \mathrm{L}$ sterile DI water). A set of three negative sample controls ( $50 \mu \mathrm{L}$ sterile DI water, $50 \mu \mathrm{L}$ buffer, $100 \mu \mathrm{L}$ 1-DOPA) was run on each microplate. Prepared plates were incubated in the dark at $30^{\circ} \mathrm{C}$ for $4 \mathrm{~h}$ and then read on a BioTek Synergy 2 microplate 
reader for $\sim 6 \mathrm{~h}$ at $30^{\circ} \mathrm{C}(410 \mathrm{~nm})$. Activity rates were calculated by subtracting the optical density of the negative sample and negative substrate controls from the values for the sample wells. This final optical density was then divided by the extinction coefficient $7.9 \mu^{-1}{ }^{-1}$ following the approach described by Hendel et al. (2005). These values were plotted vs. incubation time, and the slope of linear regression (all $R^{2}>0.95$ ) was used to calculate activity.

\subsection{Soil analysis}

Ten-gram aliquots of field-moist soil from each depth interval were centrifuged $(10 \mathrm{~min}$ at $4000 \mathrm{rpm})$ to extract porewater, which was then analyzed with a YSI3200 conductivity meter (YSI Inc., Yellow Springs, OH, USA) to determine conductivity and salinity. The precision of the conductivity measurements was $\pm 0.9 \%$ (median coefficient of variation for 15 pairs of duplicate soil samples). Following measurements of soil $\mathrm{CO}_{2}$ and $\mathrm{CH}_{4}$ production, soils were recovered from each serum bottle and analyzed for field water content (samples dried at $45^{\circ} \mathrm{C}$ ), organic matter content (loss on ignition, $5 \mathrm{~h}$ at $550^{\circ} \mathrm{C}$ ), and $\mathrm{C}$ and nitrogen $(\mathrm{N})$ contents (Costech ECS4010 elemental analyzer after sample acidification with $0.1 \mathrm{NHCl}$ to remove carbonates, Costech Analytical Technologies, Valencia, CA, USA). The precision of the elemental analysis was $\pm 0.8 \%$ for $\mathrm{C}$ and $\pm 0.9 \%$ for $\mathrm{N}$ (median coefficient of variation for 18 pairs of analytical duplicates). All soil properties were calculated on a salt-free basis (i.e., the amount of salt in porewater and in any added slurry water was subtracted from the sample weight). Salt accounted for $0.1-0.3 \%$ of the dry sample weight in soils from the control plots and up to 6-8\% in soils from the +salt plots that were slurried with brackish water.

\subsection{Statistical analyses}

The effects of long-term salinity manipulation on $\mathrm{CO}_{2}$ and $\mathrm{CH}_{4}$ flux rates were analyzed using a two-way ANOVA with field treatment and depth as fixed effects. The distributions of the $\mathrm{CO}_{2}$ and $\mathrm{CH}_{4}$ flux data were highly nonnormal and thus were $\log _{10}$ transformed prior to analysis; averages of the transformed data have been back-transformed prior to presentation in the text and figures. Soil properties (water, organic matter, $\mathrm{C}$ and $\mathrm{N}$ contents, $\mathrm{C}: \mathrm{N}$ ratios, and porewater conductivity) and extracellular enzyme activity (glucosidase, cellobiosidase, xylosidase, and phenol oxidase) were similarly analyzed, except that no data transformations were required. Whenever a significant interaction (treatment $x$ depth) effect was detected via two-way ANOVA, a series of one-way ANOVAs were used to analyze each depth or treatment level individually. All post-hoc tests were performed using Tukey's HSD. When multiple measurements were made from a specific plot $x$ depth combination (e.g., 2 serum bottles per plot per depth for $\mathrm{CO}_{2}$ and $\mathrm{CH}_{4}$ flux measurements), per-plot averages were calculated prior to statistical analyses. Pearson correlation analysis was performed to investigate how gas flux rates ( $\log _{10}$ transformed) related to soil properties and extracellular enzyme activity. Partial correlations were then performed controlling for soil organic matter content as it was strongly correlated with soil variables and extracellular enzyme activity. Statistical analyses were performed using JMP v.10 (SAS Institute, Cary, NC, USA).

The effect of short-term (several days) exposure to elevated salinity was also assessed. The relative $\mathrm{CO}_{2}$ and $\mathrm{CH}_{4}$ production ratios (i.e., production $_{\mathrm{S}=0,2 \text {, or } 5} /$ production $_{\text {field } S}$ ) in the $3-8 \mathrm{~cm}$ interval were calculated for each plot, where production $_{S}$ is the rate of anaerobic $\mathrm{CO}_{2}$ or $\mathrm{CH}_{4}$ production in soil slurries that were prepared with water at a salinity S. Field salinities were 0 for the control and + fresh plots, 2 for the + salt plots. A ratio greater than 1 indicates that changes in salinity increased rates of gas production relative to in situ field salinities, whereas a ratio less than 1 indicates that elevated salinity lowered rates of gas production. Student's $t$ tests were used to address the hypothesis that the relative $\mathrm{CO}_{2}$ and $\mathrm{CH}_{4}$ production ratios at a given treatment $\times$ salinity combination were significantly different than 1 .

\section{Results}

\section{1 $\mathrm{CO}_{2}$ and $\mathrm{CH}_{4}$ production potentials}

\subsubsection{Responses to long-term saltwater intrusion}

After $3.5 \mathrm{yr}$ of field manipulations, potential rates of $\mathrm{CO}_{2}$, $\mathrm{CH}_{4}$, and $\mathrm{CO}_{2}+\mathrm{CH}_{4}$ production were generally higher in soils from the control and +fresh plots than from the +salt plots, and were higher at the surface than at depth (Fig. 1). Two-factor ANOVA revealed a significant interaction effect between treatment and depth for all three of these variables (all $p<0.01$ ), and subsequent one-way ANOVAs indicated that the treatment effect was only statistically significant for the shallow layers of the soil $(0-3$ and $3-8 \mathrm{~cm}$ intervals, $p \leq 0.002)$. Depth effects were significant for all three treatments and all gas metrics $(p \leq 0.002)$, except that $\mathrm{CH}_{4}$ production did not change with depth for the + salt treatment $(p=0.46)$. The same patterns with treatment and depth were found regardless of whether the rates were normalized per gram of dry soil (Fig. 1), per gram of organic matter, or per gram of soil C (not shown).

Rates of $\mathrm{CO}_{2}$ production in surface soils $(0-3 \mathrm{~cm})$ were $\sim 6$ times higher in the + fresh plots than in the + salt plots, with rates in the control plots intermediate between the other treatments (Fig. 1). At $3-8 \mathrm{~cm}$, rates in the + fresh and control plots were nearly equal and were $\sim 3$ times greater than in the + salt plots. Within each treatment, $\mathrm{CO}_{2}$ production steadily decreased with increasing soil depth (all $p<0.002$ ). Changes due to depth were greatest in the + fresh plots, where $\mathrm{CO}_{2}$ 


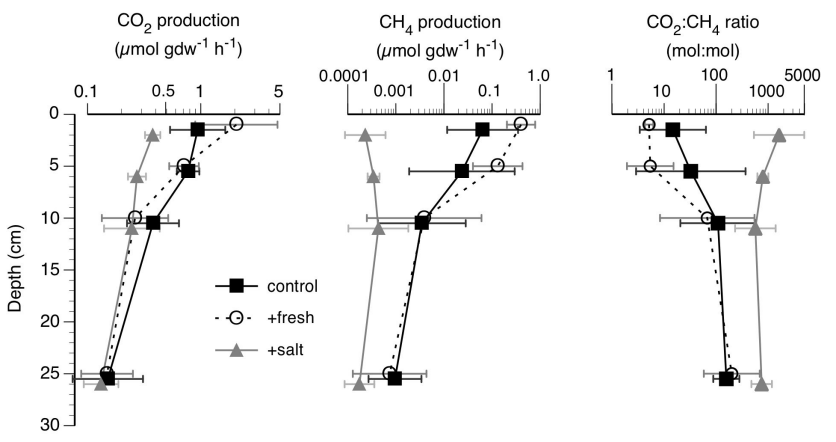

Fig. 1. Anaerobic production of $\mathrm{CO}_{2}$ and $\mathrm{CH}_{4}$, and $\mathrm{CO}_{2}: \mathrm{CH}_{4}$ ratios, at field salinities (i.e., salinity of slurry water $=0$ for control and + fresh soils, 2 for + salt soils). Values for the control treatment are plotted at the midpoint of each depth interval, with depths for the + fresh and + salt treatments jiggered by $\pm 0.5 \mathrm{~cm}$ to reduce overlap of symbols and error bars. Values are means \pm standard deviation, $n=5$ plots per data point.

production at the surface $(0-3 \mathrm{~cm})$ was $\sim 16$ times greater than it was for the deepest samples $(23-28 \mathrm{~cm})$. The comparable changes in the control ( $\sim 6$ fold) and + salt ( $\sim 3$ fold $)$ treatments were more modest. Rates of anaerobic $\mathrm{CH}_{4}$ production at $0-3$ and $3-8 \mathrm{~cm}$ depth were $2-3$ orders of magnitude higher in the control and + fresh plots than in the + salt plots (Fig. 1). For the control and +fresh plots, $\mathrm{CH}_{4}$ production decreased significantly with depth $(p<0.02)$; there was no depth-effect on $\mathrm{CH}_{4}$ production in the + salt plots.

Average rates of total anaerobic $\mathrm{C}$ mineralization (i.e., $\mathrm{CO}_{2}+\mathrm{CH}_{4}$ production, not shown) in surface soils ranged from $0.37 \mu \mathrm{mol} \mathrm{gdw}{ }^{-1} \mathrm{~h}^{-1}$ (+salt plots, gdw $=$ gram dry weight of soil) to $2.47 \mathrm{gdw}^{-1} \mathrm{~h}^{-1}$ (+fresh plots). Similar to the trends observed for $\mathrm{CO}_{2}$ and $\mathrm{CH}_{4}$ production, treatment effects for total anaerobic $\mathrm{C}$ mineralization were only observed in the surface soils $(0-3$ and $3-8 \mathrm{~cm})$. Total anaerobic $\mathrm{C}$ mineralization decreased significantly with depth $(p \leq$ 0.002 ) and was similar across all treatments for the 23$28 \mathrm{~cm}$ samples. Anaerobic $\mathrm{C}$ mineralization was dominated by $\mathrm{CO}_{2}$ production across all treatments and depths, with average $\mathrm{CO}_{2}: \mathrm{CH}_{4}$ ratios ranging from 5.1 (+fresh, $0-3 \mathrm{~cm}$ ) to 1626.2 (+salt, 0-3 cm; Fig. 1). There was a significant $(p=0.003)$ interaction for these data such that no significant depth effects were observed for the control or + salt plots. For the + fresh plots, the $\mathrm{CO}_{2}: \mathrm{CH}_{4}$ ratio was significantly higher in the deep soils (13-18 and 23-28 cm) than it was for all other depths $(0-3 \mathrm{~cm}$ and $3-8 \mathrm{~cm})$.

\subsubsection{Responses to short-term saltwater intrusion}

Short-term (several days) exposure to elevated salinity also impacted potential rates of $\mathrm{CO}_{2}$ and $\mathrm{CH}_{4}$ production in soil slurries. The effects of short-term salinity manipulation were not clear when absolute rates of $\mathrm{CO}_{2}$ and $\mathrm{CH}_{4}$ production were compared (Fig. 2a and b; $p>0.26$ ). For example, note

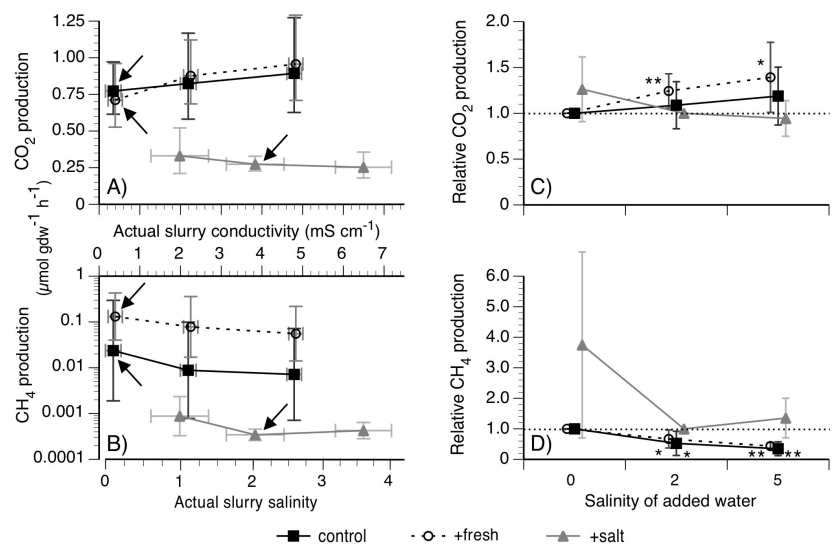

Fig. 2. Short-term effects of elevated salinity on rates of $\mathrm{CO}_{2}$ and $\mathrm{CH}_{4}$ production. (A, B) Absolute rates of $\mathrm{CO}_{2}$ and $\mathrm{CH}_{4}$ production as a function of the salinity of the soil slurry. $(\mathbf{C}, \mathbf{D})$ Rates of $\mathrm{CO}_{2}$ and $\mathrm{CH}_{4}$ production relative to gas production at field salinities (salinity $=0$ for control and + fresh soils, 2 for + salt soils). Due to porewater already present in the soil, the final salinity of the slurries was somewhat different from that of the added water (see the $x$ axis on panels (A) and (B) for actual slurry salinities). On panels (A) and (B), the data points highlighted with arrows are the same data shown for the $3-8 \mathrm{~cm}$ depth interval on Fig. 1 (i.e., rates at field salinities). On panels (C) and (D), asterisks indicate that the relative $\mathrm{CO}_{2}$ or $\mathrm{CH}_{4}$ production was significantly different than 1.0 $\left(^{*}: p \leq 0.10 ;{ }^{* *}: p \leq 0.05\right)$. Values are means \pm standard deviation, $n=5$ plots per data point.

that the error bars for $\mathrm{CH}_{4}$ production in soils from the control and + fresh plots span one or two orders of magnitude (Fig. 2b), making it impossible to statistically distinguish moderate changes in gas production rates due to the shortterm changes in salinity. Differences in absolute gas production rates between soils were driven by field treatments over the previous $3.5 \mathrm{yr}(p \leq 0.002)$. However, when relative $\mathrm{CO}_{2}$ and $\mathrm{CH}_{4}$ production ratios were calculated, it is apparent that even modest increases in salinity increased $\mathrm{CO}_{2}$ production in + fresh soils and decreased $\mathrm{CH}_{4}$ production in the + fresh and control soils (Fig. 2c and d). In soils from the + fresh plots, relative rates of $\mathrm{CO}_{2}$ production increased by $24 \%$ in the low-salinity slurries, relative to the freshwater slurries, and by $39 \%$ in the moderate salinity slurries $(p=0.04$ and 0.08 , respectively). There were no significant short-term salinity effects on relative $\mathrm{CO}_{2}$ production in soils from the control plots (Fig. 2c, $p=0.25-0.49$ ), although the $\mathrm{CO}_{2}$ production ratios tended to be greater than 1 in the low and moderate salinity slurries. Increasing or decreasing salinity for soils from the + salt plots did not change relative $\mathrm{CO}_{2}$ production ( $p=0.17-0.55)$.

The short-term effects of elevated salinity on relative rates of $\mathrm{CH}_{4}$ production were similar for soils from the control and + fresh plots. For these field treatments, relative rates of $\mathrm{CH}_{4}$ production in the low-salinity slurries were $52-67 \%$ of the rates in the freshwater slurries $(p=0.05-0.07)$, and 
were reduced even further in the moderate salinity slurries (35-46\% of the freshwater rates, $p=0.003-0.004$, Fig. $2 d$ ). Salinity did not significantly affect relative $\mathrm{CH}_{4}$ production in soils from the + salt plots $(p=0.11-0.29)$, although three of the five plots had higher rates of $\mathrm{CH}_{4}$ production (up to 7 times higher) when slurries were prepared with freshwater than with low-salinity water. Even though elevated salinity reduced relative $\mathrm{CH}_{4}$ production in soils from the control and + fresh plots (Fig. $2 \mathrm{~d}$ ), the average absolute $\mathrm{CH}_{4}$ production rates in the higher salinity treatments of the control and + fresh soils were still 1-2 orders of magnitude greater than the rates in the + salt soils (Fig. 2b).

\subsection{Extracellular enzyme activity}

Overall, enzyme activity in soils that had received $\sim 3.5$ years of experimental field manipulation was highest for phenol oxidase, ranging from $23-328 \mu \mathrm{mol} \mathrm{gdw}^{-1} \mathrm{~h}^{-1}$ (range across all treatments and depths), and was considerably lower for the other enzymes (i.e., nmol gdw ${ }^{-1} \mathrm{~h}^{-1}$; Fig. 3). Rates were similar for cellobiosidase $\left(135-775 \mathrm{nmol} \mathrm{gdw}^{-1} \mathrm{~h}^{-1}\right)$ and xylosidase $\left(94-494 \mathrm{nmol} \mathrm{gdw}^{-1} \mathrm{~h}^{-1}\right)$, but slightly higher for glucosidase $\left(545-2137 \mathrm{nmol} \mathrm{gdw}^{-1} \mathrm{~h}^{-1}\right)$. Twoway ANOVAs showed no significant interactions between depth and treatment for any of the enzymes measured (all $p>0.19)$. Treatment effects were significant for glucosidase $(p=0.002)$, cellobiosidase $(p<0.001)$, and phenol oxidase ( $p<0.001)$, though Tukey's post-hoc test revealed an incongruent response across enzyme types. Specifically, glucosidase and phenol oxidase activities were significantly lower in soils from the + salt plots relative to the controls; rates dropped by $23 \%$ and $31 \%$ respectively. In contrast, cellobiosidase activity was an average of $46 \%$ higher in soils from the + fresh plots vs. the other treatments. The effect of depth on extracellular enzyme activity was also significant (all $p<0.001$ ), except for glucosidase with $p=0.06$. Both cellobiosidase and xylosidase showed greater activity at 0 $3 \mathrm{~cm}$ compared to lower depths. At $23-28 \mathrm{~cm}$, activity of cellobiosidase was only $75 \%$ of the value at the surface layer; the comparable change was xylosidase at $60 \%$. The activity of phenol oxidase was significantly different across all depths and peaked in the $8-13 \mathrm{~cm}$ layer of soil, where rates were $49 \%$ and $135 \%$ higher than in the $0-3$ and $23-28 \mathrm{~cm}$ layers, respectively.

\subsection{Soil properties}

The long-term field manipulations altered the physicochemical characteristics of the soil (Fig. 4). For many properties, there were also significant depth effects, but there were never any treatment $x$ depth interactions $(p \geq 0.06)$. As expected, the salinity of soils in the +salt plots (average conductivity across all depths: $3.94 \mathrm{mS} \mathrm{cm}^{-1}$; salinity: 2.1 ) was significantly $(p<0.001)$ elevated compared to + fresh (conductivity: $973 \mu \mathrm{S} \mathrm{cm}^{-1}$; salinity 0.4 ) and control plots (con-

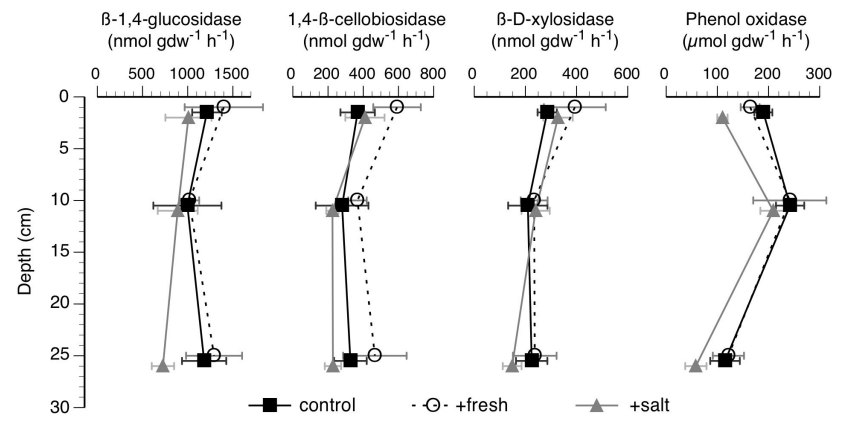

Fig. 3. Extracellular enzyme activity. Values for the control treatment are plotted at the midpoint of each depth interval, with depths for the + fresh and + salt treatments jiggered by $\pm 0.5 \mathrm{~cm}$ to reduce overlap of symbols and error bars. Values are means \pm standard deviation, $n=5$ plots per data point.

ductivity: $839 \mu \mathrm{S} \mathrm{cm}^{-1}$; salinity 0.4 ; Fig. 4). The soil water content was significantly $(p=0.004)$ lower in the + salt plots compared to the + fresh and control plots (mean across depths of $89.7 \%$ in + salt soils vs. 90.7-91.0\% in control and + fresh plots). Moreover, there were no differences in soil water content between the top three sampled depths (means across treatments: 90.8-91.9\%) but water content was significantly lower $(p<0.001)$ in the $23-28 \mathrm{~cm}$ depth interval $(87.1 \%)$. Soil organic matter content did not vary with field treatment $(p=0.13)$ but did significantly $(p<0.001)$ decrease from a mean of $70.1 \%$ at the surface $(0-3$ and $3-$ $8 \mathrm{~cm}$ ) to $55.4 \%$ in the $23-28 \mathrm{~cm}$ interval. Both soil $\mathrm{C}$ and $\mathrm{N}$ contents were significantly (both $p<0.001$ ) higher in soils from the control and +fresh plots (means across depths: $31.1-31.2 \% \mathrm{C}, 2.1 \% \mathrm{~N})$ than in the + salt plots $(28.7 \% \mathrm{C}$; $1.8 \% \mathrm{~N})$. The soil $\mathrm{C}$ and $\mathrm{N}$ contents decreased with depth $(p<0.01)$, ranging from a high of $33.0 \% \mathrm{C}$ and $2.3 \% \mathrm{~N}$ in surface soils (mean values across treatments) to a low of $26.1 \% \mathrm{C}$ and $1.6 \% \mathrm{~N}$ at the bottom of the sample cores. The soil $\mathrm{C}: \mathrm{N}$ ratio was significantly $(p<0.001)$ higher in soils from the + salt plots (means across depths of $16.0 \mathrm{~g}: \mathrm{g}$ ) than the control and + fresh plots (14.6-15.0 g: g) and increased with depth $(p<0.001$; mean across treatments of $14.2 \mathrm{~g}: \mathrm{g}$ at $0-3 \mathrm{~cm}$ vs. $17.0 \mathrm{~g}: \mathrm{g}$ in the $23-28 \mathrm{~cm}$ interval).

\subsection{Correlation analysis}

Pearson correlation analyses were performed to investigate how gas production rates (log transformed) related to soil properties and extracellular enzyme activity. Initial results indicate a significant negative correlation with salinity $\left(r_{\mathrm{CH}_{4}}=\right.$ $-0.56, r_{\mathrm{CO}_{2}}=-0.34$, and $r_{\mathrm{CO}_{2}+\mathrm{CH}_{4}}=-0.35$; all $p \leq 0.02$ ), though the strongest relationship for all gas metrics was with soil organic matter content $\left(r_{\mathrm{CH}_{4}}=0.61, r_{\mathrm{CO}_{2}}=0.80\right.$, and $r_{\mathrm{CO}_{2}+\mathrm{CH}_{4}}=0.79$; all $\left.p<0.001\right)$. Because organic matter content was also a strong correlate with soil properties $\left(r_{\text {water content }}=0.85\right.$ and $r_{\mathrm{C}: \mathrm{N}}=-0.51$; both $\left.p<0.001\right)$ and extracellular enzyme activity $\left(r_{\text {cellobiosidase }}=0.37\right.$ with 


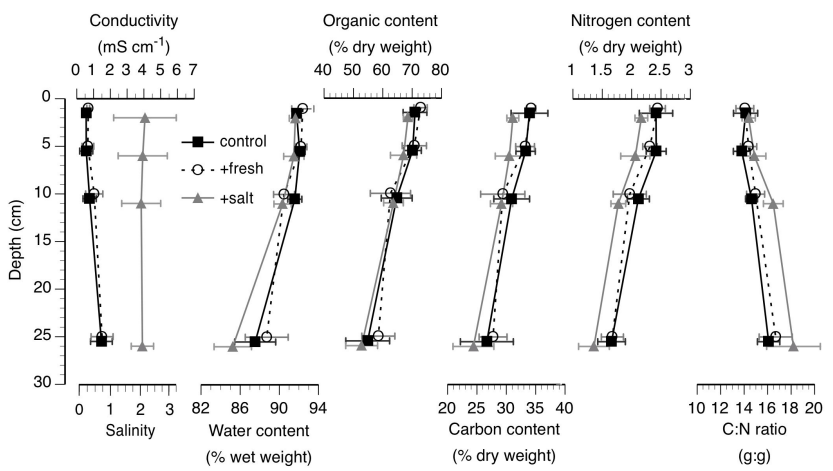

Fig. 4. Soil properties. Values for the control treatment are plotted at the midpoint of each depth interval, with depths for the + fresh and + salt treatments jiggered by $\pm 0.5 \mathrm{~cm}$ to reduce overlap of symbols and error bars. Values are means \pm standard deviation, $n=5$ plots per data point.

$p=0.01 ; r_{\text {glucosidase }}=0.25, p=0.10 ; r_{\text {xylosidase }}=0.52$ and $r_{\text {phenol oxidase }}=0.51$ with both $\left.p<0.001\right)$, a partial correlation analysis was performed controlling for the effect of organic matter. After doing so, the relationship of $\mathrm{CO}_{2}$ and $\mathrm{CO}_{2}+\mathrm{CH}_{4}$ with salinity was no longer significant (par-

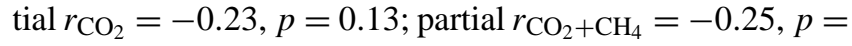
0.10 ), suggesting that any salinity-induced changes on $\mathrm{CO}_{2}$ production were mediated through organic matter availability. In contrast, $\mathrm{CH}_{4}$ production remained strongly correlated with salinity (partial $r=-0.53, p<0.001$ ) and the activity of enzymes that degrade more labile organic molecules (partial $r_{\text {glucosidase }}=0.35, p=0.02$; partial $r_{\text {cellobiosidase }}=0.27$, $p=0.07)$.

\section{Discussion}

Saltwater intrusion can affect ecosystems on timescales of days to months to decades, with the duration of impact partially driven by the mechanism that caused the saltwater intrusion (e.g., storm surge vs. drought vs. long-term sea level rise). Short-term exposure can modify the competitive balance between methanogens and sulfate reducers (Schlesinger, 1997), stimulate rates of other anaerobic processes (e.g., Fe(III) reduction, Weston et al., 2006), increase ionic stress on primary producers and microbial decomposers (Munns and Tester, 2008), and change $\mathrm{C}$ availability by desorbing soil-bound organics (Dou et al., 2005). At moderate timescales, there can be shifts in microbial community composition (Neubauer et al., 2012) that are not seen at timescales shorter than a couple months (e.g., Edmonds et al., 2009; Jackson and Vallaire, 2009). Over longer periods, saltwater intrusion can reduce plant productivity and species composition (Latham et al., 1994), potentially changing the amount and quality of autochthonous organic matter added to wetland soils. Individually and collectively, these perturbations can influence rates and pathways of $\mathrm{C}$ cycling in tidal wetland soils. Our data suggest that saltwater intrusion drives dynamic changes that may be incongruent between short (days) and longer (multiple years) timescales.

\subsection{Initial biogeochemical effects of saltwater intrusion}

Recent work has shown that tidal freshwater soils experiencing saltwater intrusion initially have elevated rates of total $\mathrm{C}$ mineralization. Generally, this is observed as increases in $\mathrm{CO}_{2}$ production, as we found in this study, where soils from the + fresh and control plots showed trends of increasing $\mathrm{CO}_{2}$ production with increasing salinity (Fig. 2a and c). Similarly, other studies have documented short-term increases in potential $\mathrm{CO}_{2}$ production, $\mathrm{CO}_{2}$ emissions, and/or the production of dissolved inorganic $\mathrm{C}$ following saltwater intrusion (Chambers et al., 2011, 2013; Weston et al., 2011; Marton et al., 2012; Jun et al., 2013), with the duration of the response being < 3 weeks (Chambers et al., 2011) up to 6 months (Weston et al., 2011). In contrast, short- to moderate-term saltwater intrusion typically results in decreased rates of $\mathrm{CH}_{4}$ production and emissions, which also occurred in our study (Fig. 2b and d). This response is supported both by thermodynamic theory (i.e., sulfate reduction is energetically favorable over methanogenesis) (Schlesinger, 1997) and the experimental results of several other saltwater intrusion studies (e.g., Weston et al., 2006; Chambers et al., 2011; Marton et al., 2012; Morse et al., 2012; Neubauer, 2013a). However, Weston et al. (2011) reported contrasting results, and documented a large, sustained increase in $\mathrm{CH}_{4}$ emissions that persisted for 5 months following simulated saltwater intrusion. One proposed explanation for this inconsistency is that soil characteristics or other site properties may mediate system responses to saltwater intrusion.

The simultaneous increase in $\mathrm{CO}_{2}$ production and decrease in $\mathrm{CH}_{4}$ production with elevated salinity (Fig. 2) suggests that there may be a tradeoff between methanogenesis (freshwater conditions) and sulfate reduction or other $\mathrm{CO}_{2}-$ producing anaerobic processes (brackish conditions) that is driven by the availability of terminal electron acceptors. The higher relative efficiency of sulfate reduction, combined with greater efficiency for other processes that may have been stimulated by the saltwater intrusion (e.g., Fe(III) reduction, Weston et al. 2006), could be important determinants of $\mathrm{C}$ mineralization rates following short-term saltwater intrusion. This sort of changeover could explain about onethird of the increase in $\mathrm{CO}_{2}$ production in soils from the + fresh plots (Fig. 2; average $\mathrm{CO}_{2}$ production increased by $\sim 0.25 \mu \mathrm{mol} \mathrm{gdw}{ }^{-1} \mathrm{~h}^{-1}$ while $\mathrm{CH}_{4}$ production declined by only $\sim 0.09 \mu \mathrm{mol} \mathrm{gdw}^{-1} \mathrm{~h}^{-1}$ ). It is also possible that the increased ionic strength associated with the brackish water treatments increased $\mathrm{C}$ availability by desorbing previously protected labile organic matter from soil surfaces. However, the small amount of relevant work with tidal freshwater soils suggests that modest increases in salinity have no effect on, or even cause decreases in, the release of dissolved organic $\mathrm{C}$ 
(Chambers et al., 2013; Jun et al., 2013; Koren et al., 2013). Moreover, at low salinities such as those in this study, the effects of ionic stress on microbial activity may not influence rates of C mineralization (Chambers et al., 2011).

In our experiment, short-term salinity manipulations did not change either $\mathrm{CO}_{2}$ or $\mathrm{CH}_{4}$ production in soils from the +salt plots (Fig. 2), most likely because the experimental manipulations during the $\sim 3.5 \mathrm{yr}$ prior to sample collection had already fostered the development of microbial communities adapted to brackish water and/or modified physico-chemical soil properties. Although elevated salinity reduced $\mathrm{CH}_{4}$ production in soils from the control and + fresh plots (Fig. 2), these rates were still 1-2 orders of magnitude higher than those from the + salt soils, indicating that the short-term effect of elevated salinity was not as large as the long-term one. For potential $\mathrm{CO}_{2}$ production, the short-term and long-term responses differed in direction (i.e., increasing vs. decreasing; compare Figs. 1 and 2). Collectively, this is evidence that the impacts of short-term saltwater intrusion differ from those that occur with longer, more sustained environmental change.

\subsection{Biogeochemical effects of sustained saltwater intrusion}

Chronic saltwater exposure can lead to persistent changes in the structure and function of plant and microbial communities, which could affect the composition of organic matter inputs to the soil, influence rates and pathways of biogeochemical $\mathrm{C}$ and nutrient dynamics, and alter ecosystem functioning (Neubauer and Craft, 2009). Below, we outline feedbacks that exist between long-term saltwater intrusion, soil C mineralization and enzyme activity, and ecosystem processes for our tidal freshwater marsh study site.

\subsubsection{Soil properties}

Three and a half years of experimental saltwater intrusion altered soil properties including salinity, water content, and C and $\mathrm{N}$ contents (Fig. 4). Assuming that all plots were similar prior to the field manipulations, subsequent differences in soil characteristics must reflect treatment-induced changes in soil composition or structure. Because soil $\mathrm{C}$ and $\mathrm{N}$ concentrations were reduced in the +salt plots but soil organic matter content did not vary, we hypothesize that the molecular composition of the soil organic matter must have changed, a speculation that is supported by the observed increase in the soil C: $\mathrm{N}$ ratio in the + salt plots (Fig. 4). Potentially, this could be related to the changes in plant community composition that co-occurred with saltwater intrusion at this site (Neubauer and Sutter, 2013) since plant species can differ in their elemental and macromolecular compositions (KögelKnabner, 2002). It is also possible that increased soil C mineralization following initial saltwater intrusion (e.g., Fig. 2) contributed to both the depletion in soil $\mathrm{C}$ content and the uti- lization of particularly labile pools of soil organic matter. Additionally, following saltwater intrusion, the increased incorporation of sulfur into the molecular structure of humic acids or other macromolecules could be contributing to treatmentrelated differences in organic matter composition and quality (Dodla et al., 2012).

These treatment effects are in addition to depth-related changes in soil properties that occur during wetland development. For historical rice fields such as our study site, there is a general successional trend from submerged wetlands dominated by aquatic plants to intertidal marshes to tidal swamp forests (Kelley and Porcher, 1995). As wetland elevation increases during succession, the decreased hydroperiod (duration and depth of tidal flooding) will lead to a reduction in mineral sediment deposition onto the wetland surface, causing newer soils to have higher organic matter content than deeper soils. We do not have data on the macromolecular composition of the soils, but the processes of humification, soil formation, and diagenesis lead to increasing lignification of organic matter as it ages (i.e., with increasing depth) (e.g., Melillo et al., 1989; DeBusk and Reddy, 1998; Dierberg et al., 2011), which suggests that the lability of organic matter is greater near the surface than at depth. Along the same depth gradient, soil $\mathrm{C}: \mathrm{N}$ ratios increased in all treatments (Fig. 4), indicating increasing $\mathrm{N}$ limitation and decreasing lability (e.g., Hessen et al., 2004; Thomsen et al., 2008).

\subsubsection{Extracellular enzyme activity}

Soil enzyme activities reflect the availability of substrates in the environment balanced with organismal demands for the oligomers, monomers, and nutrients derived from those substrates (Allison and Vitousek, 2005). This balance can be mediated by both microbial community structure (e.g., Kourtev et al., 2002) and abiotic factors that can limit enzyme synthesis and/or activity in the environment (e.g., Freeman et al., 1997; Sinsabaugh et al., 2008). For enzymes involved in $\mathrm{C}$ acquisition, activity is often positively correlated with the availability of soil organic matter and/or C content (Sinsabaugh et al., 2008; Keeler et al., 2009; Chambers et al., 2013). Our data support this for all measured enzymes (organic matter content vs. enzyme activity: $r_{\text {cellobiosidase }}=0.37, r_{\text {xylosidase }}=0.52, r_{\text {phenol oxidase }}=0.51$ with all $\left.p \leq 0.01 ; r_{\text {glucosidase }}=0.25, p=0.10\right)$ and also reveal a relationship with soil quality (e.g., $\% \mathrm{~N}$ vs. enzyme activity: $r_{\text {cellobiosidase }}=0.44, r_{\text {xylosidase }}=0.54, r_{\text {phenol oxidase }}=$ 0.47 with all $\left.p \leq 0.002 ; r_{\text {glucosidase }}=0.27, p=0.07\right)$. In addition, the activities of glucosidase and phenol oxidase were significantly reduced in the + salt plots (Fig. 3). These results are similar to those of Jackson and Vallaire (2009), who suggested that glucosidase activity in a coastal freshwater swamp soil was reduced following simulated saltwater intrusion. In contrast, Chambers et al. (2013) reported that pulsing freshwater marsh soils with brackish water did not affect the activity of glucosidase. One interpretation of the lower 
activities of glucosidase and phenol oxidase is that saltwater intrusion reduced the concentrations of cellulose and lignin, respectively, in the soil organic matter pool. This is broadly consistent with data on soil properties (see previous subsection), which also suggest that saltwater intrusion can induce a change in soil composition. Differences in extracellular enzyme activity have also been linked to changes in the composition of the soil microbial community (e.g., Kourtev et al., 2002; Gallo et al., 2004; Costa et al., 2007). Given that T-RFLP DNA fingerprinting of surface soils from our site showed significant shifts in microbial community composition (Neubauer et al., 2012), we can speculate that the shifts in the microbial community are playing a role in enzyme activity responses to saltwater intrusion.

Extracellular enzyme activity can also be constrained by abiotic factors (e.g., nutrient limitation, ionic stress, or $\mathrm{O}_{2}$ availability) that either regulate the ability of the soil microbial community to produce enzymes, or directly influence the function, stability, or persistence of the enzymes. Sinsabaugh et al. (1997) argued that enzyme synthesis involves high $\mathrm{N}$ requirements and should be restricted when $\mathrm{N}$ is scarce. At our site, soils in the +salt plots have lower $\mathrm{N}$ concentrations and higher $\mathrm{C}: \mathrm{N}$ ratios vs. soils in the other treatments (possibly due to saltwater-induced $\mathrm{NH}_{4}^{+}$desorption, e.g., Jun et al. 2013), suggesting that saltwater intrusion is increasing $\mathrm{N}$ limitation. Additionally, Jackson and Vallaire (2009) showed that simulated saltwater intrusion reduced the activities of enzymes involved in the acquisition of $\mathrm{N}$ and phosphorus ( $\mathrm{N}$-acetylglucosaminidase and phosphatase, respectively) by $\sim 20 \%$, a factor that would further limit nutrient availability. Across treatments, the activities of all enzymes were negatively correlated with salinity $\left(r_{\text {cellobiosidase }}=-0.32 . \quad r_{\text {glucosidase }}=-0.43, r_{\text {phenol oxidase }}=\right.$ -0.43 with all $p \leq 0.04 ; r_{\text {xylosidase }}=-0.13, p=0.39$ ), suggesting that salinity itself may have adverse effects on enzyme activity. Work with purified enzymes has shown that elevated salinity can reduce both phenol oxidase (Das et al., 2001) and glucosidase activity (Fang et al., 2010). There is no evidence in the literature that cellobiosidase activity responds to ionic strength (BRENDA, 2013). In contrast to the other measured enzymes, increasing salinities or $\mathrm{SO}_{4}^{2-}$ concentrations can increase xylosidase activity (Bernier et al., 1987, although we do not see evidence of that in our data). Besides salinity, another strong abiotic driver of enzyme activity is $\mathrm{O}_{2}$ availability. For example, phenol oxidase requires $\mathrm{O}_{2}$ to function (Freeman et al., 2001) so reduced plant activity at our site (Neubauer, 2013a; Neubauer and Sutter, 2013) and associated decreases in root $\mathrm{O}_{2}$ loss to the soil could contribute to the observed decrease in phenol oxidase activity in the + salt plots. It is likely that the above mechanisms collectively affect soil enzyme activity and, consequently, influence rates of soil $\mathrm{C}$ mineralization.

\subsubsection{Soil carbon mineralization}

Long-term saltwater intrusion reduced rates of soil $\mathrm{CO}_{2}$ and $\mathrm{CH}_{4}$ production in the +salt plots compared to the other treatments. This contrasts with the effects of short-term exposure to brackish water, which lead to increased rates of $\mathrm{CO}_{2}$ production but lower rates of $\mathrm{CH}_{4}$ production. There are relatively few studies that have examined the effects of long-term saltwater intrusion on mineralization and decomposition in tidal marshes, and there is conflicting evidence on the effects of salinity. After a $\sim 2.5 \mathrm{yr}$ field incubation, there were no differences in rates of $\mathrm{CO}_{2}$ production from tidal freshwater marsh soils that were either transplanted to a brackish marsh or kept in the freshwater system (SuttonGrier et al., 2011); this was attributed to the loss of labile organic matter components during the long incubation period. Working with native soils along the same salinity gradient, Neubauer et al. (2005) reported that rates of $\mathrm{CO}_{2}+\mathrm{CH}_{4}$ production were slightly lower in the brackish vs. the tidal freshwater marsh. In other estuaries, $\mathrm{C}$ mineralization (measured as $\mathrm{CO}_{2}$ emissions from cores) varies non-linearly with salinity (e.g., Smith et al., 1983; Nyman and Delaune, 1991). Patterns of $\mathrm{CH}_{4}$ production and emission along estuarine gradients are more generalizable. Largely driven by the competition between methanogens and sulfate reducers, $\mathrm{CH}_{4}$ emissions are typically greater from tidal freshwater marshes and decrease with increasing salinity (e.g., Bartlett et al., 1987; Poffenbarger et al., 2011).

In our study, soil organic matter content, and not salinity, was the strongest correlate with rates of soil $\mathrm{CO}_{2}$ and $\mathrm{CH}_{4}$ production. Given that the main effects of treatment and depth were similar when gas production rates were normalized per gram of dry soil or per gram of organic material, we suggest that the observed non-linear relationship between organic content and gas production rates inherently incorporates differences in the amount of organic material as well as its quality (lability), which is itself affected by salinity. Thus, factors such as the degree of humification, the lignocellulose index, and lignin : nitrogen ratios, which were not measured but often vary with depth and are good predictors of decomposition rates (e.g., Janssen, 1984; Melillo et al., 1989), may be driving a portion of the correlation between organic content and gas production rates.

In an effort to disentangle the relationships between saltwater intrusion, soil properties, extracellular enzyme activity, and rates of soil $\mathrm{C}$ mineralization, we applied our knowledge of this system and the results from partial correlation analyses to develop the following conceptual model. In tidal freshwater marshes, long-term saltwater intrusion alters plant community composition (Neubauer and Sutter, 2013) and reduces rates of annual gross ecosystem production by $26-44 \%$ (Neubauer, 2013b). Our analysis suggests that the long-term effect of saltwater intrusion on soil $\mathrm{CO}_{2}$ production is indirect, mediated through the effects of elevated salinity on the quantity and quality of autochthonous 
Table 1. Comparison of areal fluxes $\left(\mathrm{mg} \mathrm{C} \mathrm{m}^{-2} \mathrm{~min}^{-1}\right)$ of $\mathrm{CO}_{2}$ and $\mathrm{CH}_{4}$ based on (i) production rates measured in anaerobic slurry bottles and (ii) emission rates measured in the field using dark ecosystem metabolism chambers. The field flux measurements were made in Nov 2011, roughly two weeks prior to the collection of soil that was used in the slurry experiments (Neubauer, 2013b). Values are means, with ranges shown in parentheses $(n=5)$. Rates and ratios were $\log _{10}$ transformed, averaged by treatment, and then back-transformed for presentation. Within a column, values with the same superscripted letters are not significantly different from each other (one-way ANOVA of $\log _{10}$ transformed data, followed by Tukey's HSD multiple comparison test). An asterisk indicates that a slurry: field flux ratio was significantly different from 1.0 (Student's $t$ test).

\begin{tabular}{|c|c|c|c|c|c|c|}
\hline Treatment & $\begin{array}{r}\text { Slurry } \mathrm{CO}_{2} \\
\left(\mathrm{mg} \mathrm{C} \mathrm{m}^{-2} \mathrm{~min}^{-1}\right)\end{array}$ & $\begin{array}{r}\text { Field } \mathrm{CO}_{2} \\
\left(\mathrm{mg} \mathrm{C} \mathrm{m}^{-2} \mathrm{~min}^{-1}\right)\end{array}$ & $\begin{array}{r}\mathrm{CO}_{2} \text {, Slurry : Field } \\
\text { (unitless) }\end{array}$ & $\begin{array}{r}\text { Slurry } \mathrm{CH}_{4} \\
\left(\mathrm{mg} \mathrm{C} \mathrm{m}^{-2} \mathrm{~min}^{-1}\right)\end{array}$ & $\begin{array}{r}\text { Field } \mathrm{CH}_{4} \\
\left(\mathrm{mg} \mathrm{C} \mathrm{m}^{-2} \mathrm{~min}^{-1}\right)\end{array}$ & $\begin{array}{r}\mathrm{CH}_{4} \text {, Slurry: Fielc } \\
\text { (unitless }\end{array}$ \\
\hline \multirow[t]{2}{*}{ control } & $1.90^{\mathrm{a}}$ & $2.37^{\mathrm{ab}}$ & $0.80^{\mathrm{a}}$ & $0.06^{\mathrm{a}}$ & $0.10^{\mathrm{a}}$ & $0.62^{\circ}$ \\
\hline & $(1.12-3.34)$ & $(1.59-3.19)$ & $(0.35-1.19)$ & $(0.008-0.28)$ & $(0.05-0.20)$ & $(0.04-6.12)$ \\
\hline \multirow[t]{2}{*}{+ fresh } & $2.14^{\mathrm{a}}$ & $2.88^{\mathrm{a}}$ & $0.74^{\mathrm{a}}$ & $0.34^{\mathrm{a}}$ & $0.11^{\mathrm{a}}$ & $3.01^{\circ}$ \\
\hline & $(1.45-3.01)$ & $(2.27-4.09)$ & $(0.36-1.03)$ & $(0.14-0.81)$ & $(0.05-0.24)$ & $(0.75-14.10)$ \\
\hline \multirow[t]{2}{*}{+ salt } & $1.09^{\mathrm{b}}$ & $1.56^{\mathrm{b}}$ & $0.70^{\mathrm{a}}$ & $0.002^{\mathrm{b}}$ & $0.05^{a}$ & $0.03^{\mathrm{b}, *}$ \\
\hline & $(0.76-1.38)$ & $(1.20-2.30)$ & $(0.47-1.15)$ & $(0.0007-0.005)$ & $(0.03-0.11)$ & $(0.01-0.11)$ \\
\hline
\end{tabular}

organic matter inputs to the soil. However, we cannot discount that initial exposure to saltwater accelerated rates of soil C mineralization (Fig. 2) and could have contributed to the depletion of high-quality, labile soil organic matter. In contrast to our analysis of soil $\mathrm{CO}_{2}$ production, salinity, organic matter content, and the activities of glucosidase and cellobiosidase directly influence $\mathrm{CH}_{4}$ production. The influence of salinity on $\mathrm{CH}_{4}$ production was similar over both short and longer timescales (Figs. 1 and 2) and likely driven by the role of seawater $\mathrm{SO}_{4}^{2-}$ in promoting sulfate reduction at the expense of methanogenesis. There was a positive relationship between soil $\mathrm{CH}_{4}$ production and the activities of glucosidase and cellobiosidase. These enzymes are among those that produce the monomers and oligomers used by fermenters in anaerobic environments, with the end products of fermentation used as substrates for methanogenesis (Megonigal et al., 2004). In other wetlands, glucosidase activity was also positively correlated with $\mathrm{CH}_{4}$ production (Morrissey et al., 2013; Freeman et al., 1997), likely because the amount of substrate available for fermentation indirectly affects the amount of substrate available for methanogenesis (Uz and Ogram, 2006). If glucosidase and cellobiosidase are indicative of the quantity of their associated substrate (cellulose), the composition of organic matter must also be important in determining the rate of $\mathrm{CH}_{4}$ production. This conceptual model suggests that saltwater intrusion into tidal freshwater wetlands would decrease $\mathrm{CH}_{4}$ production by at least three mechanisms: suppression by sulfate reduction, a reduction in organic matter inputs, and a change in the macromolecular composition of that material.

\subsubsection{Linking soil biogeochemistry to ecosystem-scale processes}

Subsurface metabolic processes influence emissions of $\mathrm{CO}_{2}$ and $\mathrm{CH}_{4}$ from wetlands to the atmosphere. We extrapolated our slurry $\mathrm{CO}_{2}$ and $\mathrm{CH}_{4}$ production potentials (per gdw soil, Fig. 1) to an areal basis (per $\mathrm{m}^{2}$ ) using depth-specific soil bulk density values from parallel cores collected in each plot. Gas production rates for depth intervals that were not sampled in this study (13-18 and 18-23 cm) were estimated by linear interpolation. Average potential $\mathrm{CO}_{2}$ production rates (integrated to $28 \mathrm{~cm}$ depth) were roughly twice as high in the control and + fresh plots relative to the + salt plots (Table 1). Further, the production rates were similar in magnitude to marsh-atmosphere emissions of $\mathrm{CO}_{2}$ and $\mathrm{CH}_{4}$ that were measured from each plot roughly two weeks prior to soil collection (field fluxes measured under dark conditions using ecosystem metabolism chambers, methods follow Neubauer, 2013a). Rates of potential $\mathrm{CH}_{4}$ production were 30-170 times greater in the control and + fresh plots vs. the + salt plots. In contrast, there were no significant differences in $\mathrm{CH}_{4}$ emissions from the field plots at this time of year. Average ratios of slurry $\mathrm{CO}_{2}$ production : field $\mathrm{CO}_{2}$ emissions for each treatment ranged from 0.7 to 0.8 (Table 1). This ratio did not vary by treatment, and none of the ratios was significantly different than 1.0 (that is, $\mathrm{CO}_{2}$ production calculated from the slurry incubations was statistically similar to rates of $\mathrm{CO}_{2}$ emissions from field plots). Similarly, there were no significant differences in the $\mathrm{CH}_{4}$ slurry : field emission ratios for the control and + fresh plots, but this ratio was significantly lower in the + salt plots (Table 1 ).

We might expect that soil $\mathrm{CO}_{2}$ production would be less than field $\mathrm{CO}_{2}$ emissions (since the field measurements quantify $\mathrm{CO}_{2}$ produced by both plant and soil sources), but that slurry $\mathrm{CH}_{4}$ production would be similar to or greater than field $\mathrm{CH}_{4}$ emissions (depending on the importance of $\mathrm{CH}_{4}$ oxidation). Neubauer (2013a) estimated that $\mathrm{CO}_{2}$ emissions from plant and soil sources at this site were similar in magnitude, which suggests that the in situ $\mathrm{CO}_{2}$ soil production rate is overestimated by the soil slurries, likely because the incubation temperature of $25^{\circ} \mathrm{C}$ was greater than in situ soil temperatures of $12.0 \pm 1.0^{\circ} \mathrm{C}$ (at $5 \mathrm{~cm}$ ) to $14.8 \pm 0.5^{\circ} \mathrm{C}$ (at $25 \mathrm{~cm}$; Neubauer, 2013b). Alternately, the slurries may reflect true rates of soil $\mathrm{CO}_{2}$ production, but a significant fraction of the $\mathrm{CO}_{2}$ from soil organic matter mineralization in 
the field may be exported in dissolved form rather than as gaseous $\mathrm{CO}_{2}$ that is emitted to the atmosphere and detected during field measurements (e.g., Fig. 1 in Megonigal and Neubauer, 2009 and references therein). In contrast, the export of dissolved $\mathrm{CH}_{4}$ is probably not very large relative to emissions to the atmosphere because of the relatively low solubility of $\mathrm{CH}_{4}$. For the +salt plots, the $\mathrm{CH}_{4}$ production potentials accounted for only $\sim 3 \%$ of the $\mathrm{CH}_{4}$ that was emitted from the field plots, a significantly lower percentage than in the control and + fresh plots (Table 1). Although there are multiple reasons to expect that slurry-based gas production measurements might differ from field fluxes, differences in the ratio of slurry production to field emissions between the different treatments can be informative. We hypothesize that there is tight coupling between primary production, plant-derived exudates, and methanogenesis (e.g., Whiting and Chanton, 1993; Megonigal et al., 1999; and as suggested by our conceptual model), such that the isolation of soils from the influences of plants (e.g., by collecting soil cores) leads to the rapid depletion of labile lowmolecular weight substrates and a corresponding decrease in rates of $\mathrm{CH}_{4}$ production. Due to higher primary production (Neubauer, 2013a) and larger soil C content (Fig. 4) in the control and + fresh plots, it may take considerably longer for substrate depletion to limit methanogenesis in these other treatments vs. saltwater-exposed soils.

\section{Conclusions}

Because a new set of ecosystem interactions and feedbacks develops as an initial disturbance transitions into a sustained shift in the physico-chemical environment, there can be substantial differences between short-term and long-term responses to environmental change. We demonstrated that the effect of saltwater intrusion on $\mathrm{C}$ biogeochemistry of soils from tidal freshwater marshes follows this paradigm, with shifting interactions between components of the integrated plant-microbial-soil system. Specifically, elevated salinity over short timescales (days) resulted in an increase in rates of anaerobic soil $\mathrm{CO}_{2}$ production with a concomitant decrease in rates of $\mathrm{CH}_{4}$ production. In part, these changes were likely driven by a shift between methanogenesis (more important in freshwater conditions) and the thermodynamically more efficient process of sulfate reduction (enhanced following saltwater intrusion). In contrast, our data suggest that longer-term (years) saltwater intrusion reduced rates of both soil $\mathrm{CO}_{2}$ and $\mathrm{CH}_{4}$ production by affecting $\mathrm{C}$ inputs to the soil, the lability of soil $\mathrm{C}$ pools, and the activity of extracellular enzymes that carry out the initial hydrolysis and oxidation steps of mineralization. It remains to be seen how the trajectory of tidal freshwater wetland responses to saltwater intrusion will change over even longer timescales (e.g., decades) as brackish-tolerant plant and microbial communities become established.
Acknowledgements. We thank A. Rotella, R. Schwartz, O. De Meo, E. Morrissey, and C. Dang for expert help in the field and laboratory. Additionally, a small platoon of technicians, students, staff, and volunteers assisted in transporting water to the study plots in order to maintain the experimental manipulations. Significantly, we thank B. Jewell, M. Ammons, and the staff at Brookgreen Gardens for allowing access to the study site and generously permitting $\mathrm{S}$. C. N. to turn a "6-month long" project into one that ultimately lasted almost four years. We also thank three anonymous referees for comments that improved the presentation and interpretation of our data. This research was supported by grants to S. C. N. from the University of South Carolina, Office of Research and Health Sciences Research Funding Program and the US Department of Energy's Office of Science (BER) through the Coastal Center of the National Institute for Climatic Change Research at Tulane University (DOE Grant \# DE-FC02-06ER64298). This is contribution \#1684 from the University of South Carolina's Belle W. Baruch Institute for Marine and Coastal Sciences.

Edited by: K. Küsel

\section{References}

Allison, S. D. and Vitousek, P. M.: Responses of extracellular enzymes to simple and complex nutrient inputs, Soil Biol. Biochem., 37, 937-944, doi:10.1016/j.soilbio.2004.09.014, 2005.

Baldwin, D. S., Rees, G. N., Mitchell, A. M., Watson, G., and Williams, J.: The short-term effects of salinization on anaerobic nutrient cycling and microbial community structure in sediment from a freshwater wetland, Wetlands, 26, 455-464, 2006.

Barendregt, A. and Swarth, C. W.: Tidal freshwater wetlands: Variation and changes, Estuar. Coast., 36, 445-456, doi:10.1007/s12237-013-9626-z, 2013.

Bartlett, K. B., Bartlett, D. S., Harriss, R. C., and Sebacher, D. I.: Methane emissions along a salt marsh salinity gradient, Biogeochemistry, 4, 183-202, 1987.

Bernier Jr., R., Desrochers, M., Paice, M. G., and Yaguchi, M.: Isolation and characterization of $\beta$-xylosidase from a recombinant Escherichia, J. Gen. Appl. Microbiol., 33, 409-419, 1987.

BRENDA, The Comprehensive Enzyme Information System, http: //www.brenda-enzymes.org (last access: 24 May 2013), 2013.

Bridgham, S. D., Pastor, J., Dewey, B., Weltzin, J. F., and Updegraff, K.: Rapid carbon response of peatlands to climate change, Ecology, 89, 3041-3048, 2008.

Bridgham, S. D., Cadillo-Quiroz, H., Keller, J. K., and Zhuang, Q.: Methane emissions from wetlands: biogeochemical, microbial, and modeling perspectives from local to global scales, Glob. Change Biol., 19, 1325-1346, doi:10.1111/gcb.12131, 2013.

Chambers, L. G., Reddy, K. R., and Osborne, T. Z.: Shortterm response of carbon cycling to salinity pulses in a freshwater wetland, Soil Sci. Soc. Am. J., 75, 2000-2007, doi:10.2136/sssaj2011.0026, 2011.

Chambers, L. G., Osborne, T. Z., and Reddy, K. R.: Effect of salinity-altering pulsing events on soil organic carbon loss along an intertidal wetland gradient: a laboratory experiment, Biogeochemistry, 115, 363-383, doi:10.1007/s10533-013-9841-5, 2013. 
Conrad, R.: The global methane cycle: Recent advances in understanding the microbial processes involved, Environ. Microbiol. Rep., 1, 285-292, doi:10.1111/j.1758-2229.2009.00038.x, 2009.

Costa, A. L., Paixão, S. M., Caçador, I., and Carolino, M.: CLPP and EEA profiles of microbial communities in salt marsh sediments, J. Soils Sediment, 7, 418-425, 2007.

Das, M., Chakraborty, T. K., and Mukherjee, M.: Purification and characterization of a growth-regulating laccase from Pleurotus florida, J. Basic Microb., 41, 261-267, 2001.

DeBusk, W. F. and Reddy, K. R.: Turnover of detrital organic carbon in a nutrient-impacted Everglades marsh, Soil Sci. Soc. Am. J., 62, 1460-1468, 1998.

Dierberg, F. E., DeBusk, T. A., Larson, N. R., Kharbanda, M. D., Chan, N., and Gabriel, M. C.: Effects of sulfate amendments on mineralization and phosphorus release from South Florida (USA) wetland soils under anaerobic conditions, Soil Biol. Biochem., 43, 31-45, doi:10.1016/j.soilbio.2010.09.006, 2011.

Dodla, S. K., Wang, J. J., and Cook, R. L.: Molecular composition of humic acids from coastal wetland soils along a salinity gradient, Soil Sci. Soc. Am. J., 76, 1592-1605, doi:10.2136/sssaj2011.0346, 2012.

Dou, F., Ping, C.-L., Guo, L., and Jorgenson, T.: Estimating the impact of seawater on the production of soil water-extractable organic carbon during coastal erosion, J. Environ. Qual., 37, 2368 74, doi:10.2134/jeq2007.0403, 2005.

Edmonds, J. W., Weston, N. B., Joye, S. B., Mou, X., and Moran, M. A.: Microbial community response to seawater amendment in low-salinity tidal sediments, Microb. Ecol., 58, 558-68, doi:10.1007/s00248-009-9556-2, 2009.

Fang, Z., Fang, W., Liu, J., Hong, Y., Peng, H., Zhang, X., Sun, B., and Xiao, Y.: Cloning and characterization of a $\beta$-glucosidase from marine microbial metagenome with excellent glucose tolerance, J. Microbiol. Biotechn., 20, 1351-1358, 2010.

Freeman, C., Liska, G., Ostle, N., Lock, M. A., Hughes, S., Reynolds, B., and Hudson, J.: Enzymes and biogeochemical cycling in wetlands during a simulated drought, Biogeochemistry, 1, 177-187, 1997.

Freeman, C., Ostle, N., and Kang, H.: An enzymic "latch" on a global carbon store, Nature, 409, p. 149, doi:10.1038/35051650, 2001.

Gallo, M., Amonette, R., Lauber, C., Sinsabaugh, R. L., and Zak, D. R.: Microbial community structure and oxidative enzyme activity in nitrogen-amended north temperate forest soils, Microb. Ecol., 48, 218-229, doi:10.1007/s00248-003-9001-x, 2004.

Hendel, B., Sinsabaugh, R. L., and Marxsen, J.: Lignin-degrading enzymes: Phenoloxidase and peroxidase, in: Methods to Study Litter Decomposition: A Practical Guide, edited by: Graça, M. A., Bärlocher, F., and Gessner, M. O., Springer, Dordrecht, the Netherlands, 273-278, 2005.

Hessen, D. O., Ågren, G. I., Anderson, T. R., Elser, J. J., and De Ruiter, P. C.: Carbon sequestration in ecosystems: The role of stoichiometry, Ecology, 85, 1179-1192, 2004.

Jackson, C. R. and Vallaire, S. C.: Effects of salinity and nutrients on microbial assemblages in Louisiana wetland sediments, Wetlands, 29, 277-287, 2009.

Janssen, B.: A simple method for calculating decomposition and accumulation of "young" soil organic matter, Plant Soil, 76, 297304,1984
Jun, M., Altor, A. E., and Craft, C. B.: Effects of increased salinity and inundation on inorganic nitrogen exchange and phosphorus sorption by tidal freshwater floodplain forest soils, Georgia (USA), Estuar. Coast., 36, 508-518, doi:10.1007/s12237-0129499-6, 2013.

Keeler, B. L., Hobbie, S. E., and Kellogg, L. E.: Effects of long-term nitrogen addition on microbial enzyme activity in eight forested and grassland sites: Implications for litter and soil organic matter decomposition, Ecosystems, 12, 1-15, doi:10.1007/s10021-0089199-z, 2009.

Keller, J. K., Bauers, A. K., Bridgham, S. D., Kellogg, L. E., and Iversen, C. M.: Nutrient control of microbial carbon cycling along an ombrotrophic-minerotrophic peatland gradient, J. Geophys. Res., 111, G03006, doi:10.1029/2005JG000152, 2006.

Kelley, B. J. and Porcher, R. D.: Vegetational status of the freshwater tidal marshes of the upper Cooper River, South Carolina Department of Health and Environmental Control, Office of Coastal Resource Management, Charleston, South Carolina, USA, 1995.

Kögel-Knabner, I.: The macromolecular organic composition of plant and microbial residues as inputs to soil organic matter, Soil Biol. Biochem., 34, 139-162, 2002.

Koren, L. M., McCallister, S. L., Neubauer, S. C., Jaffé, R., and Yamashita, Y.: Influence of salinity variations on the desorption and lability of soil organic carbon associated with tidal freshwater marshes, Aquatic Geosciences, in preparation, 2013.

Kourtev, P., Ehrenfeld, J., and Häggblom, M.: Exotic plant species alter the microbial community structure and function in the soil, Ecology, 83, 3152-3166, 2002.

Laiho, R.: Decomposition in peatlands: Reconciling seemingly contrasting results on the impacts of lowered water levels, Soil Biol. Biochem., 38, 2011-2024, doi:10.1016/j.soilbio.2006.02.017, 2006.

Latham, P. J., Pearlstine, L. G., and Kitchens, W. M.: Species association changes across a gradient of fresh-water, oligohaline, and mesohaline tidal marshes along the lower Savannah River, Wetlands, 14, 174-183, 1994.

Lindroth, A., Lund, M., Nilsson, M., Aurela, M., Christensen, T. R., Laurila, T., Rinne, J., Riutta, T., Sagerfors, J., Ström, L., Tuovinen, J.-P., and Vesala, T.: Environmental controls on the $\mathrm{CO}_{2}$ exchange in north European mires, Tellus B, 59, 812-825, doi:10.1111/j.1600-0889.2007.00310.x, 2007.

Marton, J. M., Herbert, E. R., and Craft, C. B.: Effects of salinity on denitrification and greenhouse gas production from laboratory-incubated tidal forest soils, Wetlands, 32, 347-357, doi:10.1007/s13157-012-0270-3, 2012.

Marx, M., Wood, M., and Jarvis, S.: A microplate fluorimetric assay for the study of enzyme diversity in soils, Soil Biol. Biochem., 33, 1633-1640, 2001.

Megonigal, J. P. and Neubauer, S. C.: Biogeochemistry of tidal freshwater wetlands, in: Coastal Wetlands: An Integrated Ecological Approach, edited by: Perillo, G. M. E., Wolanski, E., Cahoon, D. R., and Brinson, M. M., Elsevier, 535-562, 2009.

Megonigal, J. P., Whalen, S. C., Tissue, D. T., Bovard, B. D., Albert, D. B., and Allen, A. S.: A plant-soil-atmosphere microcosm for tracing radiocarbon from photosynthesis through methanogenesis, Soil Sci. Soc. Am. J., 63, 665-671, 1999.

Megonigal, J. P., Hines, M. E., and Visscher, P. T.: Anaerobic metabolism: linkages to trace gases and aerobic metabolism, 
in: Biogeochemistry, edited by: Schlesinger, W. H., ElsevierPergamon, Oxford, UK, 317-424, 2004.

Melillo, J. M., Aber, J. D., Linkins, A. E., Ricca, A., Fry, B., and Nadelhoffer, K. J.: Carbon and nitrogen dynamics along the decay continuum?, Plant litter to soil organic matter, Plant Soil, 115, 189-198, 1989.

Mitra, S., Wassmann, R., and Vlek, P. L. G.: An appraisal of global wetland area and its organic carbon stock, Current Science, 88, 25-35, 2005.

Morrissey, E. M., Berrier, D. J., Neubauer, S. C., and Franklin, R. B.: Using microbial communities and extracellular enzymes to link soil organic matter characteristics to greenhouse gas production in a tidal freshwater wetland, Biogeochemistry, doi:10.1007/s10533-013-9894-5, in press, 2013.

Morse, J. L., Ardón, M., and Bernhardt, E. S.: Greenhouse gas fluxes in southeastern U.S. coastal plain wetlands under contrasting land uses, Ecol. Appl., 22, 264-280, 2012.

Munns, R. and Tester, M.: Mechanisms of salinity tolerance, Ann. Rev. Plant Biol., 59, 651-681, doi:10.1146/annurev.arplant.59.032607.092911, 2008.

Neubauer, S. C.: Ecosystem responses of a tidal freshwater marsh experiencing saltwater intrusion and altered hydrology, Estuar. Coast., 36, 491-507, doi:10.1007/s12237-011-9455-x, 2013a.

Neubauer, S. C.: Environmental drivers of tidal freshwater marsh responses to saltwater intrusion: Insights from a multi-year field manipulation experiment, Ecosystems, in preparation, 2013b.

Neubauer, S. C. and Craft, C. B.: Global change and tidal freshwater wetlands: Scenarios and impacts, in: Tidal Freshwater Wetlands, edited by: Barendregt, A., Whigham, D. F., and Baldwin, A. H., Backhuys, Leiden, the Netherlands, 253-266, 2009.

Neubauer, S. C. and Sutter, L. A.: Ecosystem carbon fixation regulated by tidal freshwater marsh plant responses to environmental disturbance, Wetlands, in preparation, 2013.

Neubauer, S. C., Givler, K., Valentine, S., and Megonigal, J. P.: Seasonal patterns and plant-mediated controls of subsurface wetland biogeochemistry, Ecology, 86, 3334-3344, 2005.

Neubauer, S. C., Franklin, R. B., and Piehler, M. F.: Saltwater intrusion into tidal freshwater marshes drives shifts at all levels of ecosystem organization, 9th INTECOL International Wetlands Conference, Orlando, Florida, US, 3-8 June, 2012.

Nyman, J. A. and Delaune, R. D.: $\mathrm{CO}_{2}$ emission and soil Eh responses to different hydrological conditions in fresh, brackish, and saline marsh soils, Limnol. Oceanogr., 36, 1406-1414, 1991.

Poffenbarger, H. J., Needelman, B. A., and Megonigal, J. P.: Salinity influence on methane emissions from tidal marshes, Wetlands, 31, 831-842, doi:10.1007/s13157-011-0197-0, 2011.

Schlesinger, W. H.: Biogeochemistry: An analysis of global change, Academic Press, San Diego, CA, USA, 1997.

Segers, R.: Methane production and methane consumption: A review of processes underlying wetland methane fluxes, Biogeochemistry, 41, 23-51, 1998.
Sinsabaugh, R. L.: Enzymic analysis of microbial pattern and process, Biol. Fert. Soils, 17, 69-74, 1994.

Sinsabaugh, R. L., Findlay, S., Franchini, P., and Fischer, D.: Enzymatic analysis of riverine bacterioplankton production, Limnol. Oceanogr., 42, 29-38, 1997.

Sinsabaugh, R. L., Lauber, C. L., Weintraub, M. N., Ahmed, B., Allison, S. D., Crenshaw, C., Contosta, A. R., Cusack, D., Frey, S., Gallo, M. E., Gartner, T. B., Hobbie, S. E., Holland, K., Keeler, B. L., Powers, J. S., Stursova, M., Takacs-Vesbach, C., Waldrop, M. P., Wallenstein, M. D., Zak, D. R., and Zeglin, L. H.: Stoichiometry of soil enzyme activity at global scale, Ecol. Lett., 11, 1252-64, doi:10.1111/j.1461-0248.2008.01245.x, 2008.

Smith, C. J., DeLaune, R. D., and Patrick Jr., W. H.: Carbon dioxide emission and carbon accumulation in coastal wetlands, Estuar. Coast. Shelf Sci., 17, 21-29, 1983.

Stursova, M., Crenshaw, C. L., and Sinsabaugh, R. L.: Microbial responses to long-term $\mathrm{N}$ deposition in a semiarid grassland, $\mathrm{Mi}-$ crob. Ecol., 51, 90-98, doi:10.1007/s00248-005-5156-y, 2006.

Sundareshwar, P. V, Morris, J. T., Koepfler, E. K., and Fornwalt, B.: Phosphorus limitation of coastal ecosystem processes, Science, 299, 563-565, 2003.

Sutton-Grier, A. E., Keller, J. K., Koch, R., Gilmour, C., and Megonigal, J. P.: Electron donors and acceptors influence anaerobic soil organic matter mineralization in tidal marshes, Soil Biol. Biochem., 43, 1576-1583, doi:10.1016/j.soilbio.2011.04.008, 2011.

Thomsen, I. K., Petersen, B. M., Bruun, S., Jensen, L. S., and Christensen, B. T.: Estimating soil C loss potentials from the $\mathrm{C}$ to $\mathrm{N}$ ratio, Soil Biol. Biochem., 40, 849-852, doi:10.1016/j.soilbio.2007.10.002, 2008.

Updegraff, K., Bridgham, S. D., Pastor, J., and Weishampel, P.: Hysteresis in the temperature response of carbon dioxide and methane production in peat soils, Biogeochemistry, 43, 253-272, 1998.

Uz, I. and Ogram, A. V.: Cellulolytic and fermentative guilds in eutrophic soils of the Florida Everglades, FEMS Microbiol. Ecol., 57, 396-408, doi:10.1111/j.1574-6941.2006.00120.x, 2006.

Weston, N. B., Dixon, R. E., and Joye, S. B.: Ramifications of increased salinity in tidal freshwater sediments: Geochemistry and microbial pathways of organic matter mineralization, J. Geophys. Res., 111, G01009, doi:10.1029/2005JG000071, 2006.

Weston, N. B., Vile, M. A., Neubauer, S. C., and Velinsky, D. J.: Accelerated microbial organic matter mineralization following saltwater intrusion into tidal freshwater marsh soils, Biogeochemistry, 102, 135-151, doi:10.1007/s10533-010-9427-4, 2011.

Whiting, G. J. and Chanton, J. P.: Primary production control of methane emission from wetlands, Nature, 364, 794-795, 1993. 